\title{
Ethinylestradiol and testosterone have divergent effects on circulating IGF system components in adolescents with constitutional tall stature
}

\author{
Raoul P A Rooman, Lieve Op De Beeck, Manou Martin ${ }^{1}$, Jaap van Doorn ${ }^{2}$, Subburaman Mohan ${ }^{3}$ \\ and Marc V L Du Caju \\ Department of Pediatrics and ${ }^{1}$ Department of Biological Chemistry, Antwerp University Hospital, Belgium, ${ }^{2}$ Laboratory of Metabolic and Endocrine \\ Diseases, Wilhelmina Children's Hospital, University Medical Center, Utrecht, the Netherlands and ${ }^{3}$ Musculoskeletal Disease Center, JLP VA Medical \\ Center, Loma Linda, California 92357, USA \\ (Correspondence should be addressed to R Rooman; Email: raoul.rooman@ua.ac.be)
}

\begin{abstract}
Objective: Pharmacological doses of estrogens or testosterone are used to limit the final height of girls or boys with constitutional tall stature but the mechanism behind this growth inhibition is still debated. We therefore studied the changes in the circulating components of the insulin-like growth factor (IGF) system during high dose sex steroid therapy.

Design and methods: Twenty three girls and twenty boys with constitutional tall stature were treated with $100 \mu \mathrm{g}$ ethinylestradiol per day or $250 \mathrm{mg}$ testosterone ester every 14 days respectively. In 19 girls and 18 boys, the levels of IGF-I, free IGF-I, IGF-II, acid-labile subunit (ALS) and IGF binding proteins (IGFBP)-2 to -6 were measured before and 3-6 months after the start of therapy (group 1). In 18 girls and 11 boys, samples were collected at the end of therapy and 3 to 6 months afterwards (group 2). Fourteen girls and nine boys belonged to both groups. All parameters were measured by radioimmunoassay or ELISA.

Results: Levels of IGF-I were decreased significantly by estrogen treatment but remained unchanged during testosterone treatment. Free IGF-I decreased during estrogen treatment but increased during testosterone therapy. Estrogens increased IGF-II and testosterone reduced it. The important reduction of IGFBP-2 during estrogen therapy is not reproduced by androgen therapy, neither is the stimulation by estrogens of IGFBP-4. IGFBP-3 is not modulated by either sex steroid. We found that IGFBP-6 is up-regulated by testosterone but not by estrogens; the reverse is true for ALS, which increased during estrogen treatment but remained unchanged during testosterone treatment. Conclusions: Our findings demonstrate that androgens and estrogens exert differential effects on the circulating levels of several IGF components.
\end{abstract}

European Journal of Endocrinology 152 597-604

\section{Introduction}

Pharmacological doses of estrogens or testosterone are used to limit the final height of girls or boys with constitutional tall stature (1). The mechanism behind this growth inhibition is still debated and may involve an interaction with the circulating insulin-like growth factor (IGF) system.

This system is composed of two ligands, IGF-I and IGF-II, which are bound in the circulation to at least 6 different high-affinity IGF-binding proteins (IGFBPs) $(2-4)$. Since there is a $50 \%$ molar excess of binding proteins over the IGFs in serum, only a minute fraction of IGF is in the free, unbound form. Approximately 75\% of IGF-I is bound to IGFBP-3 and this IGFBP-3-IGF-I complex is itself associated to an acid-labile subunit
(ALS) to form a ternary complex that is unable to cross the vascular endothelium. The IGF-binding proteins therefore determine the pharmacokinetics and tissue distribution of the IGFs and hence their biological activity (3).

We previously reported that total IGF-I, free IGF-I and IGFBP-2 decreased and IGFBP-4 increased during high dose estrogen therapy (5). High doses of testosterone are used to limit adult height in boys with tall stature and we wondered whether testosterone induces similar changes in the circulating IGF components. In the present study we report the change in the circulating components of the IGF system during a high dose testosterone treatment in tall boys and compared these changes to the effects of high dose estrogen therapy in tall girls. 


\section{Patients and methods}

Forty-three constitutionally tall children (23 girls and 20 boys) were included in this study, approved by the ethical review board of the Antwerp University Hospital. Informed consent was obtained from patients and parents.

The diagnosis of constitutional tall stature was based on (a) familial occurrence of tall stature (height of one or both parents $>2$ standard deviations (S.D.) above the mean), according to the standards of Freeman et al. (6), (b) predicted adult height of more than $178 \mathrm{~cm}$ for girls and $195 \mathrm{~cm}$ for boys and (c) exclusion of endocrine and other disorders that may explain their tall stature.

The girls received $0.1 \mathrm{mg}$ ethinylestradiol every day at bedtime. This treatment was supplemented with $10 \mathrm{mg}$ medroxyprogesterone acetate for the first 12 days of each month. Tall boys were treated with $250 \mathrm{mg}$ testosterone enanthate intramuscularly every 2 weeks.

In 19 girls and 18 boys, EDTA plasma and serum samples were collected between 0900 and $1200 \mathrm{~h}$, at the start of therapy and after 2 to 4 months of treatment (group 1). In 18 girls and 11 boys, samples were collected at the end of therapy, and 3 to 6 months afterwards (group 2). Fourteen girls and nine boys belonged to both groups.

Total IGF-I was measured in EDTA plasma by radioimmunoassay (RIA) (Biosource Europe, Nivelles, Belgium) after acid-ethanol extraction (7). Interassay variability was less than $10 \%$. The concentration of IGF-II was determined after Sep-Pak C18 column extraction by a specific RIA (8). IGFBP-2 was analyzed by an RIA (DSL 7100) developed by Diagnostic Systems Laboratories (Webster, Texas, USA) using a rabbit polyclonal IGFBP-2 antiserum. IGFBP-3 was measured in a solid phase immunoradiometric assay (BC 1040; Biocode, Liège, Belgium) using a mouse anti-IGFBP-3 monoclonal antibody. Serum IGFBP-4 levels were determined by an RIA using recombinant human IGFBP-4 as tracer and standard, and antibodies against recombinant human IGFBP-4 raised in guinea pigs (9). Serum IGFBP-5 levels were also determined by an RIA using recombinant human IGFBP-5 as tracer and standard, and antibodies against recombinant human IGFBP-5 raised in guinea pigs (10). IGFBP-6 was measured by radioimmunoassay using a rabbit polyclonal antiserum raised against a synthetic fragment containing residues 90-118 that was also used as a tracer. Technical details and data on reproducibility and stability after storage have been described elsewhere (11).

Easy dissociable or 'free' IGF-I was measured by a two-site immunoradiometric assay (DSL 9400; Diagnostic Systems Laboratories).

The acid-labile subunit was determined by ELISA (DSL 10-8200; Diagnostic Systems Laboratories). Due to the large interassay variability, the samples of a particular patient were always measured in the same assay. For the patients in group 1, the concentrations of ALS found in the samples obtained during treatment were expressed as a fraction of those taken before treatment which was set at $100 \%$. Similarly, in group 2 the results for the samples taken after treatment were expressed as a fraction of those obtained at the end of treatment.

All results are reported as medians and their range is indicated in brackets. The statistical analysis of the results was performed by Wilcoxon signed ranks test (SPSS version 11; SPSS, Chicago, IL, USA).

\section{Results}

\section{Patient characteristics (Table 1)}

The girls had a median age of 13.7 years and a median bone age of 13.5 years at the start of treatment. At the end of 1 to 2.5 years of treatment (group 2), the girls had a median bone age of 15.5 years. Treatment of the boys was started at a median age of 14.6 and a bone age of 14.25 years when their testicular volume was at least $8 \mathrm{ml}$. After a median 1.5 years of treatment (group 2), the boys had a median bone age of 17.5 years.

\section{Changes in total IGF-I, IGF-II and free-dissociable IGF-I (Fig. 1)}

Total plasma IGF-I decreased significantly from 530 $(270-660) \mathrm{ng} / \mathrm{ml}$ to $350(210-440) \mathrm{ng} / \mathrm{ml}$ during estrogen treatment and rose again from 258 (220$400) \mathrm{ng} / \mathrm{ml}$ to $450(170-680) \mathrm{ng} / \mathrm{ml}$ after cessation of therapy. In contrast, total IGF-I did not change during testosterone treatment in boys.

During the first 3 months of estrogen therapy, IGF-II transiently increased from $407(186-612) \mathrm{ng} / \mathrm{ml}$ to 471 (365-693) ng/ml. The IGF-II levels at the end of

Table 1 Characteristics of boys and girls at the start (group 1) and at the end (group 2) of treatment. The results are shown as medians and ranges.

\begin{tabular}{lccccc}
\hline & \multicolumn{2}{c}{ Boys } & & \multicolumn{2}{c}{ Girls } \\
\cline { 2 - 3 } & Group 1 (start) $(n=18)$ & Group 2 (stop) $(n=11)$ & & Group 1 (start) $(n=19)$ & Group 2 (stop) $(n=18)$ \\
\hline Age (years) & $14.6(13.4-18.4)$ & $16.05(14.4-19.3)$ & & $13.7(11.5-5.7)$ & $15.7(12.7-17.2)$ \\
Bone age (years) & $14.25(12.75-15.50)$ & $17.50(15.5-18.0)$ & & $13.50(12.25-15.00)$ & $15.50(13.50-17.00)$ \\
Height (cm) & $186.5(180.0-201.0)$ & $191.9(187.9-197)$ & & $176.4(172.6-181.9)$ & $180.8(178.3-182.7)$ \\
Predicted height $(\mathrm{cm})$ & $199.7(195.2-214.1)$ & - & & $182.3(178.4-189.3)$ & \\
\hline
\end{tabular}

www.eje-online.org 

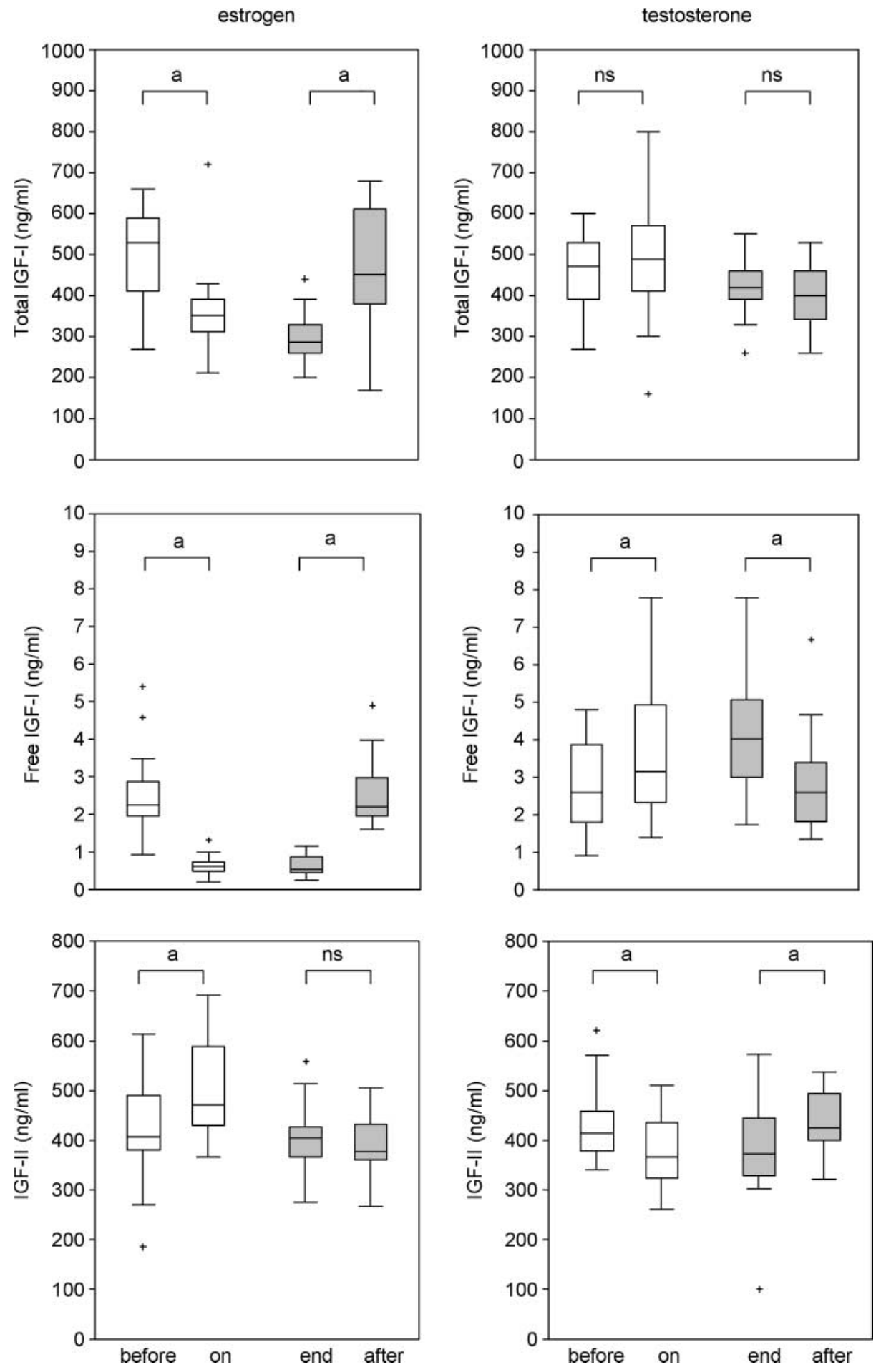

Figure 1 Changes in total IGF-I, free IGF-I and IGF-II before (before), after 3 months (on), at the end (end) and 3-6 months after estrogen or testosterone therapy (after) of constitutionally tall children. The box represents the median and the 25th and 75th centiles; the whiskers show the 10th and 90th centile. The plus signs represent outliers. a, $P \leq 0.05$ (Wilcoxon signed ranks test); ns, not statistically significant.

therapy (group 2) however were not different from the values found at the start of treatment (group 1). In contrast, testosterone reduced IGF-II concentration from $415(341-620) \mathrm{ng} / \mathrm{ml}$ to $365(262-511) \mathrm{ng} / \mathrm{ml}$. After the cessation of treatment, the levels recovered to pretreatment values. Both steroids also exerted an opposite effect on free IGF-I which fell significantly from $2.3(0.9-5.4) \mathrm{ng} / \mathrm{ml}$ to $0.6(0.2-1.5) \mathrm{ng} / \mathrm{ml}$ during treatment with estrogen but rose during testosterone therapy from $2.6(0.9-4.8) \mathrm{ng} / \mathrm{ml}$ to $3.1(1.7-$ $7.8) \mathrm{ng} / \mathrm{ml}$ after 3 months and to $4.0(1.7-7.8) \mathrm{ng} / \mathrm{ml}$ at the end of treatment. 


\section{Modulation of IGFBP-2 to -6 (Fig. 2)}

Estrogen treatment reduced circulating IGFBP-2 levels from $482(185-1120) \mathrm{ng} / \mathrm{ml}$ to $208(69-437)$ $\mathrm{ng} / \mathrm{ml}$. The IGFBP-2 concentrations rose again after the end of therapy. In contrast, testosterone treatment increased IGFBP-2 from $578(240-879) \mathrm{ng} / \mathrm{ml}$ to 717 (223-1260) ng/ml. Serum IGFBP-2 concentrations at the end of treatment in group 2 were comparable to the levels before treatment in group 1 and remained unchanged 3 to 6 months after the end of treatment.

The circulating IGFBP-3 concentrations decreased slightly after 3 months of testosterone treatment but not during estrogen treatment. In both cases, the levels at the end of treatment in group 2 were lower than at the start of treatment in group 1. No further changes were seen 3-6 months after the end of therapy.

Serum IGFBP-4 levels increased during estrogen treatment and decreased afterwards while testosterone had no effect on this binding protein. IGFBP-5 remained unaffected by either steroid.

The IGFBP-6 levels in the circulation increased during testosterone administration and decreased afterwards. Treatment with estrogen tended to induce an opposite effect.

In testosterone-treated boys the ALS in serum decreased to $97 \pm 11 \%$ of pretreatment values and rose again to $104 \pm 5 \%$ of the values at the end of treatment. In girls, serum ALS rose significantly to $119 \pm 15 \%$ during estrogen treatment. Three to six months after the end of therapy, the ALS concentration decreased to $86 \pm 12 \%$ of the levels obtained at the end of treatment.

\section{Discussion}

High dose estrogen treatment reduced the levels of total IGF-I as reported previously in a smaller group of tall girls (5). Similarly in adults, estrogens invariably decrease plasma IGF-I levels whether given in low doses as an oral contraceptive in young adult women $(12,13)$ or as hormonal replacement therapy in postmenopausal women $(14,15)$ or in high doses to human volunteers (16), acromegalics (17) or male to female transsexuals (18). This effect is probably explained by a direct effect of estrogens on IGF-I gene transcription $(19,20)$. Although the administration of testosterone to pubertal tall boys yields a similar degree of growth inhibition, we did not observe any effect of testosterone on their total IGF-I levels. It has been reported that plasma IGF-I increases after administering testosterone to normal men (21), hypogonadal men $(22,23)$, boys with delayed puberty $(24-30)$ or female to male transsexuals (31). However, when testosterone was given to men with growth hormone (GH) deficiency total and free IGF-I remained unchanged $(24,32,33)$. This implies that the increase in IGF-I by substitutive doses of testosterone are mediated by GH. We speculate that testosterone did not increase total IGF-I in these tall pubertal boys because $\mathrm{GH}$ secretion is already maximally stimulated by the endogenous testosterone production.

Both sex steroids had minor but opposite effects on the total IGF-II concentrations in serum. In a previous study on a limited number of patients we reported an increase in IGF-II when estrogen treatment was discontinued (5) but this finding is not reproduced in this larger group. The effect of estrogens on circulating IGF-II levels remains controversial. Most authors found that oral contraception (13), and oral $(34,35)$ or transdermal (34) estrogen supplementation had little effect on IGF-II levels in postmenopausal women or in Turner patients (36). However, a significant decrease in IGF-II was found after 5 years in a longitudinal study of estrogen replacement in perimenopausal women (Danish Osteoporosis Prevention Study) (37) and estrogen withdrawal by a gonadotropin releasing hormone $(\mathrm{GnRH})$ agonist in adult women with endometriosis resulted in a $40 \%$ increase in total IGFII concentrations (38). IGF-II levels also decreased in postmenopausal women treated with high doses of diethylstilbestrol (DES) as anti-tumor therapy (39). There are no data in the literature on changes in IGF-II during testosterone therapy. One possible explanation for our findings is that IGF-II competes with IGF-I for the same binding sites on the IGF binding proteins and therefore rises when IGF-I decreases (estrogen effect) and falls when IGF-I increases. However, the possibility of a direct but opposite effect of both steroids on IGF-II gene transcription cannot be excluded.

Before any treatment, the girls had slightly lower levels of IGFBP-2 than the boys. Estrogens further reduced the IGFBP-2 serum concentration to less than $50 \%$ of pretreatment levels but testosterone increased serum IGFBP-2, at least during the first months of therapy. These opposite effects may explain why adolescent girls and young women have slightly lower levels of IGFBP-2 than men of the same age (40). The reduction of IGFBP-2 by estrogens was not seen in women taking oral contraceptives (13) nor in postmenopausal women or Turner patients on hormone replacement therapy $(35,36)$. In contrast, IGFBP-2 decreased in postmenopausal women treated with high doses of DES for metastatic breast cancer (38). These data suggest that serum IGFBP-2 levels decrease only at high doses of estrogens. The increase in serum IGFBP-2 caused by testosterone therapy has not been reported before but testosterone increased IGFBP-2 synthesis in human fetal osteoblasts in vitro (41).

Before any treatment the IGFBP-3 levels were similar in boys and girls. At the end of treatment serum IGFBP3 was $15-20 \%$ lower in both sexes. The decrease in IGFBP-3 was already noticeable after 3 months of testosterone in the boys. In humans, concentrations of estrogens within the normal physiological range have 

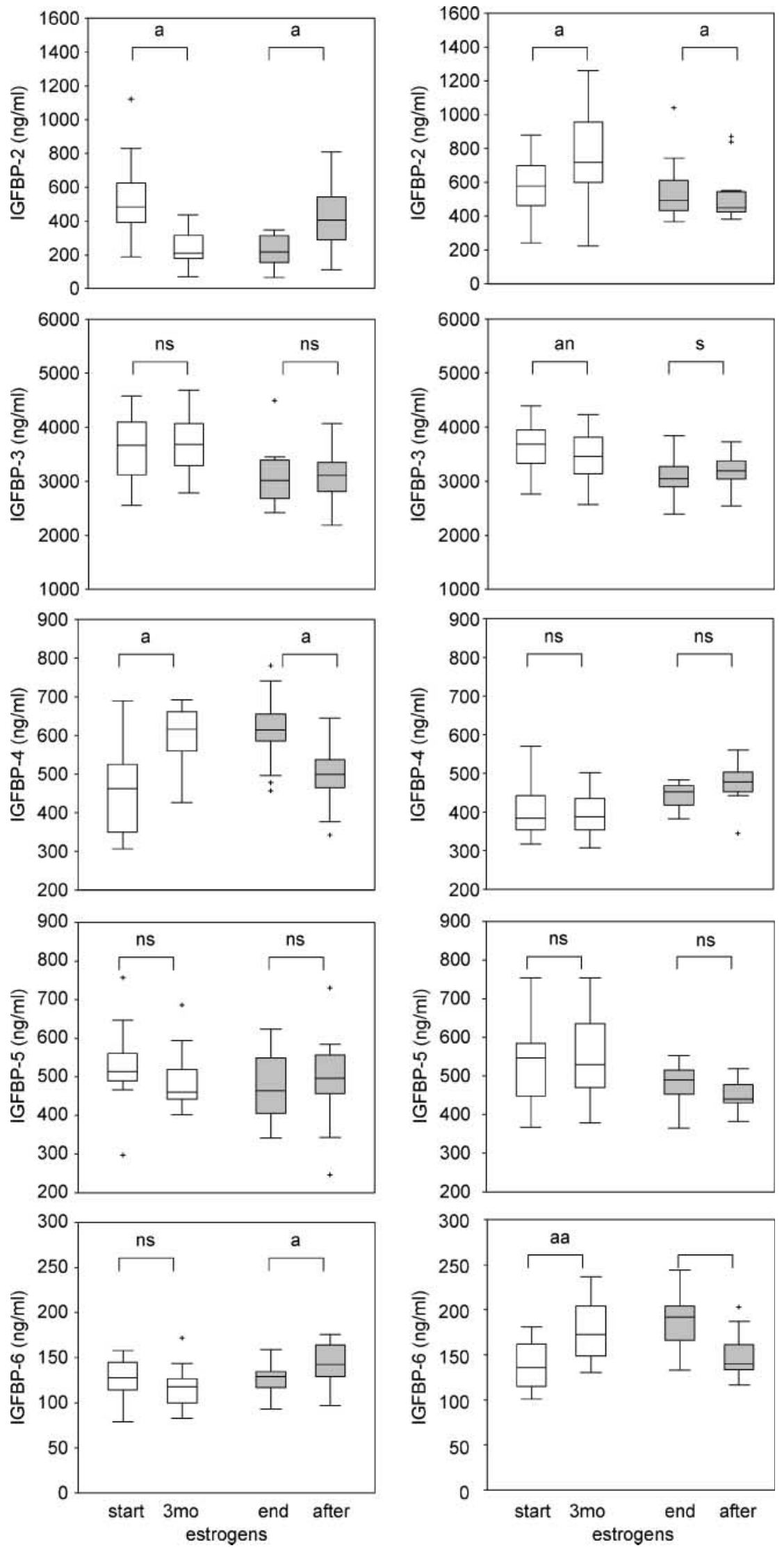

Figure 2 Levels of IGFBP-2 to -6 at the start (start), 3 months after the start $(3 \mathrm{mo})$, at the end (end) and 3-6 months after the cessation of high dose estrogen or testosterone therapy (after) in constitutionally tall adolescents. The box represents the median and the 25th and 75th centiles; the whiskers show the 10th and 90 th centile. The plus signs represent outliers. a, $P \leq 0.05$

(Wilcoxon signed ranks test); ns, not statistically significant. 
little or no effect on serum IGFBP-3 levels. For example, during the normal menstrual cycle IGFBP-3 levels remain constant $(13,42-44)$. In postmenopausal women, oral estrogen supplementation caused no change $(34,37,44,45)$ or a limited decrease $(35$, 47) in IGFBP-3 levels. Transdermal estrogen supplementation had no effect on IGFBP-3 either (34, $45,46,48)$. Circulating IGFBP-3 levels also remained unchanged in adult Turner women who started estrogen therapy. However, a 30\% decrease in IGFBP-3 was also noted in postmenopausal women receiving high doses of DES for metastatic breast cancer (38). It is plausable that IGFBP-3 only decreases during prolonged exposure to high doses of estrogens. A low or high dose of testosterone did not change serum IGFBP-3 levels in normal men $(21,29,49,50)$, female to male transsexuals (31) or oophorectomized women (51).

The changes in serum IGFBP-3 levels, observed in the present study, are not the consequence of changes in ALS, which remained unaffected by testosterone but was clearly increased by estrogen. The latter finding agrees with the reduction in ALS reported in untreated postmenopausal women (47).

We found an important increase in serum IGFBP-4 during estrogen treatment. Estrogens are known to stimulate IGFBP-4 mRNA synthesis in ovariectomized animals $(52-54)$ and increase the amount of IGFBP-4 in the serum of postmenopausal women receiving estrogen substitution (55), of women on oral contraceptives (13) and of women receiving high doses of DES for breast cancer (39). Since IGFBP-4 is generally considered an inhibitor of IGF-I action (56, 57 ) it may mediate the growth inhibiting effect of estrogens. Serum IGFBP-4 did not change during the first months of testosterone therapy but the serum levels were higher in group 2 at the end of therapy than in group 1. One hypothesis is that some of the testosterone is aromatized to estrogens, causing an increase in IGFBP-4. This hypothesis, however, does not explain why the IGFBP-4 concentrations remain higher when all treatment is stopped.

Mohan et al. (10) reported a rise in IGFBP-5 during pubertal development in girls. Estrogens were therefore hypothesized to regulate IGFBP-5 synthesis. Our study shows that serum IGFBP-5 concentrations are not significantly influenced by either ethinylestradiol or testosterone. Therefore, the rise in IGFBP-5 during puberty in females is probably the result of an estrogen-dependent increase in GH secretion during puberty. There are no data on the effect of testosterone therapy on IGFBP-5 concentrations.

We confirmed that there is little difference in serum IGFBP-6 between boys and girls during puberty (11). High doses of estrogens and testosterone had opposite effects on IGFBP-6. Estrogens tended to decrease while testosterone significantly increased serum IGFBP-6 levels. We are not aware of any data in the literature on the modulation of IGFBP-6 by sex steroids.

The opposite effects of estrogen and testosterone on IGF-I, free IGF-I and IGF-II are difficult to explain on the basis of changes in the IGFBPs. For example, IGFBP-2 and IGFBP-6 have a higher affinity for IGF-II than for IGF-I. Because testosterone increases both IGFBP-2 and IGFBP-6, one would expect an increase in IGF-II levels. However, the contrary is found. The concentrations of most IGFBPs, with the exception of IGFBP-3, rise during testosterone therapy, yet free IGF-I also rises. Other mechanisms must therefore be involved, such as a direct effect on gene expression or a change in affinity of the binding proteins for their ligands by limited proteolysis.

We have previously speculated that the growth inhibition caused by estrogens is partly explained by a dramatic fall in free IGF-I and the generation of inhibiting IGFBPs such as IGFBP-4 and an IGFBP-3 fragment (5). Unfortunately, a reliable assay to quantify this inhibitory IGFBP-3 fragment is currently unavailable. Boys treated with high doses of testosterone also have higher levels of estradiol due to aromatization of testosterone. This mechanism cannot, however, be invoked to explain the growth inhibition caused by testosterone. Our data indicate that any effects of increased levels of estradiol in these boys must be overruled by those of testosterone.

We did not provide any direct evidence that the changes in the circulating IGF system are important mediators in the growth inhibitory effects of high doses of sex steroids. Indeed, estrogens and androgens have pleiotropic effects on many biological processes that occur, for example, in the growth plate. Correlation studies between the degree of growth inhibition and the changes in the various IGF components may be a first step to find a causal link, but definitive answers should be provided by selectively adding or removing each of these components.

\section{Acknowledgements}

This study was supported by a grant from the Belgian Study Group for Pediatric Endocrinology (R R) and NIH grant AR31062 (S M).

\section{References}

1 Drop SL, De Waal WJ \& De Muinck Keizer-Schrama SM. Sex steroid treatment of constitutionally tall stature. Endocrine Reviews $199819540-558$.

2 Jones JI \& Clemmons DR. Insulin-like growth factors and their binding proteins: biological actions. Endocrine Reviews 199516 $3-34$.

3 Rajaram S, Baylink DJ \& Mohan S. Insulin-like growth factorbinding proteins in serum and other biological fluids: regulation and functions. Endocrine Reviews 199518 801-831.

4 Kelley KM, Oh Y, Gargosky SE, Gucev Z, Matsumoto T, Hwa V, $\mathrm{Ng} \mathrm{L}$, Simpson DM \& Rosenfeld RG. Insulin-like growth factorbinding proteins (IGFBPs) and their regulatory dynamics. 
International Journal of Biochemistry and Cell Biology 199528 619-637.

5 Rooman RP, De Beeck LO, Martin M, Van Doorn J, Mohan S \& Du Caju MVL. IGF-I, IGF-II, 'free' IGF-I and IGF-binding proteins-2 to -6 during high-dose oestrogen treatment in constitutionally tall girls. European Journal of Endocrinology 2002146 $823-829$.

6 Freeman JV, Cole TJ, Chinn S, Jones PR, White EM \& Preece MA. Cross sectional stature and weight reference curves for the UK, 1990. Archives of Diseases in Childhood 199573 17-24.

7 Daughaday WH, Mariz IK \& Blethen SL. Inhibition of access of bound somatomedin to membrane receptor and immunobinding sites: a comparison of radioreceptor and radioimmunoassay of somatomedin in native and acid-ethanol-extracted serum. Journal of Clinical Endocrinology and Metabolism 198051 781-788.

8 Rikken B, Van Doorn J, Ringeling A, Van den Brande JL, Massa G \& Wit JM. Plasma levels of insulin-like growth factor (IGF)-I, IGF-II and IGF-binding protein-3 in the evaluation of childhood growth hormone deficiency. Hormone Research $1998 \mathbf{5 0}$ $166-176$.

9 Honda Y, Landale EC, Strong DD, Baylink DJ \& Mohan S. Recombinant synthesis of insulin-like growth factor-binding protein-4 (IGFBP-4): development, validation, and application of a radioimmunoassay for IGFBP-4 in human serum and other biological fluids. Journal of Clinical Endocrinology and Metabolism 199681 1389-1396.

10 Mohan S, Libanati C, Dony C, Lang K, Srinivasan N \& Baylink DJ. Development, validation, and application of a radioimmunoassay for insulin-like growth factor binding protein-5 in human serum and other biological fluids. Journal of Clinical Endocrinology and Metabolism $1995802638-2645$.

11 Van Doorn J, Ringeling AM, Shmueli SS, Kuijpers MC, HokkenKoelega AC, Buul-Offers SC \& Jansen M. Circulating levels of human insulin-like growth factor binding protein-6 (IGFBP-6) in health and disease as determined by radioimmunoassay. Clinical Endocrinology 199950 601-609.

12 Jernstrom H \& Olsson H. Suppression of plasma insulin-like growth factor-I levels in healthy, nulliparous, young women using low dose oral contraceptives. Gynecologic and Obstetric Investigation 199438 261-265.

13 Westwood M, Gibson JM, Pennells LA \& White A. Modification of plasma insulin-like growth factors and binding proteins during oral contraceptive use and the normal menstrual cycle. American Journal of Obstetrics and Gynecology 1999180 530-536.

14 Dawson-Hughes B, Stern D, Goldman J \& Reichlin S. Regulation of growth hormone and somatomedin-C secretion in postmenopausal women: effect of physiological estrogen replacement. Journal of Clinical Endocrinology and Metabolism 198663 424-432.

15 Weissberger AJ, Ho KK \& Lazarus L. Contrasting effects of oral and transdermal routes of estrogen replacement therapy on 24-hour growth hormone $(\mathrm{GH})$ secretion, insulin-like growth factor I, and GH-binding protein in postmenopausal women. Journal of Clinical Endocrinology and Metabolism 199172 374-381.

16 Wiedemann E, Schwartz E \& Frantz AG. Acute and chronic estrogen effects upon serum somatomedin activity, growth hormone, and prolactin in man. Journal of Clinical Endocrinology and Metabolism $197642942-952$.

17 Clemmons DR \& Underwood LE. Somatomedin-C/insulin-like growth factor I in acromegaly. Journal of Clinical Endocrinology and Metabolism 198615 629-653.

18 Meyer WJ III, Furlanetto RW \& Walker PA. The effect of sex steroids on radioimmunoassayable plasma somatomedin C concentrations. Journal of Clinical Endocrinology and Metabolism $1982551184-1187$.

19 McCarthy TL, Ji C, Shu H, Casinghino S, Crothers K, Rotwein P \& Centrella M. 17Beta-estradiol potently suppresses cAMP-induced insulin-like growth factor-I gene activation in primary rat osteoblast cultures. Journal of Biological Chemistry 1997272 $18132-18139$.
20 Fournier B, Gutzwiller S, Dittmar T, Matthias G, Steenbergh P \& Matthias P. Estrogen receptor (ER)-alpha, but not ER-beta, mediates regulation of the insulin-like growth factor I gene by antiestrogens. Journal of Biological Chemistry 2001276 35444-35449.

21 Hobbs CJ, Plymate SR, Rosen CJ \& Adler RA. Testosterone administration increases insulin-like growth factor-I levels in normal men. Journal of Clinical Endocrinology and Metabolism $1993 \mathbf{7 7}$ $776-779$.

22 Liu L, Merriam GR \& Sherins RJ. Chronic sex steroid exposure increases mean plasma growth hormone concentration and pulse amplitude in men with isolated hypogonadotropic hypogonadism. Journal of Clinical Endocrinology and Metabolism 1987 $64651-656$.

23 Hagenfeldt Y, Linde K, Sjoberg HE, Zumkeller W \& Arver S. Testosterone increases serum 1,25-dihydroxyvitamin D and insulin-like growth factor-I in hypogonadal men. International Journal of Andrology 199215 93-102.

24 Parker MW, Johanson AJ, Rogol AD, Kaiser DL \& Blizzard RM. Effect of testosterone on somatomedin-C concentrations in prepubertal boys. Journal of Clinical Endocrinology and Metabolism 1984 58 87-90.

25 Jasper HG. Somatomedin response to testosterone stimulation in children with male pseudohermaphroditism, cryptorchidism, anorchia, or micropenis. Journal of Clinical Endocrinology and Metabolism $198560910-913$.

26 Keenan BS, Richards GE, Ponder SW, Dallas JS, Nagamani M \& Smith ER. Androgen-stimulated pubertal growth: the effects of testosterone and dihydrotestosterone on growth hormone and insulin-like growth factor-I in the treatment of short stature and delayed puberty. Journal of Clinical Endocrinology and Metabolism 199376 996-1001.

27 Keenan BS, Richards GE, Mercado M, Dallas JS, Eakman GD \& Baumann G. Androgen regulation of growth hormone binding protein. Metabolism $1996 \mathbf{4 5} 1521-1526$.

28 Soliman AT, Khadir MM \& Asfour M. Testosterone treatment in adolescent boys with constitutional delay of growth and development. Metabolism $1995 \mathbf{4 4} 1013-1015$.

29 Giustina A, Scalvini T, Tassi C, Desenzani P, Poiesi C, Wehrenberg WB, Rogol AD \& Veldhuis JD. Maturation of the regulation of growth hormone secretion in young males with hypogonadotropic hypogonadism pharmacologically exposed to progressive increments in serum testosterone. Journal of Clinical Endocrinology and Metabolism 199782 1210-1219.

30 Crowne EC, Wallace WH, Moore C, Mitchell R, Robertson WH, Holly JM \& Shalet SM. Effect of low dose oxandrolone and testosterone treatment on the pituitary-testicular and GH axes in boys with constitutional delay of growth and puberty. Clinical Endocrinology 199746 209-216.

31 van Kesteren P, Lips P, Deville W, Popp-Snijders C, Asscheman H, Megens J \& Gooren L. The effect of one-year cross-sex hormonal treatment on bone metabolism and serum insulin-like growth factor-I in transsexuals. Journal of Clinical Endocrinology and Metabolism $1996812227-2232$.

32 Cara JF, Burstein S, Cuttler L, Moll GW Jr \& Rosenfield RL. Growth hormone deficiency impedes the rise in plasma insulin-like growth factor I levels associated with precocious puberty. Journal of Pediatrics 1989115 64-68.

33 Fisker S, Norrelund H, Juul A, Skakkebaek NE, Christiansen JS \& Jorgensen JO. The growth hormone $(\mathrm{GH})$-insulin-like growth factor axis during testosterone replacement therapy in GH-treated hypopituitary males. Growth Hormone and IGF Research 200111 104-109.

34 Helle SI, Omsjo IH, Hughes SC, Botta L, Huls G, Holly JM \& Lonning PE. Effects of oral and transdermal oestrogen replacement therapy on plasma levels of insulin-like growth factors and IGF binding proteins 1 and 3: a cross-over study. Clinical Endocrinology $199645727-732$.

35 Heald A, Selby PL, White A \& Gibson JM. Progestins abrogate estrogen-induced changes in the insulin-like growth factor axis. 
American Journal of Obstetrics and Gynecology $2000 \mathbf{1 8 3}$ 593-600.

36 Gravholt CH, Frystyk J, Flyvbjerg A, Orskov H \& Christiansen JS. Reduced free IGF-I and increased IGFBP-3 proteolysis in Turner syndrome: modulation by female sex steroids. American Journal of Physiology, Endocrinology and Metabolism 2001280 E308-E314.

37 Vestergaard P. Hermann AP, Orskov H \& Mosekilde L. Effect of sex hormone replacement on the insulin-like growth factor system and bone mineral: a cross-sectional and longitudinal study in 595 perimenopausal women participating in the Danish Osteoporosis Prevention Study. Journal of Clinical Endocrinology and Metabolism $1999842286-2290$.

38 Poiraudeau S, Roux C, De Ceuninck F, Tsagris L, Borderie D, Cherruau B, Dumontier MF \& Corvol M. Circulating insulin-like growth factor system changes in women with acute estrogen deficiency induced by GnRH agonist. Osteoporosis International $19977463-470$

39 Helle SI, Geisler J, Anker GB, Leirvaag B, Holly JM \& Lonning PE. Alterations in the insulin-like growth factor system during treatment with diethylstilboestrol in patients with metastatic breast cancer. British Journal of Cancer 200185 147-151.

40 Yu H, Mistry J, Nicar MJ, Khosravi MJ, Diamandis A, Van Doorn J \& Juul A. Insulin-like growth factors (IGF-I, free IGF-I and IGF-II) and insulin-like growth factor binding proteins (IGFBP-2, IGFBP3, IGFBP-6, and ALS) in blood circulation. Journal of Clinical Laboratory Analysis 199913 166-172.

41 Gori F, Hofbauer LC, Conover CA \& Khosla S. Effects of androgens on the insulin-like growth factor system in an androgen-responsive human osteoblastic cell line. Endocrinology $1999 \mathbf{1 4 0}$ 5579-5586.

42 Wang HS, Lee JD \& Soong YK. Serum levels of insulin-like growth factor I and insulin-like growth factor-binding protein-1 and -3 in women with regular menstrual cycles. Fertility and Sterility 1995 63 1204-1209.

43 Thierry van Dessel HJ, Chandrasekher Y, Yap OW, Lee PD, Hintz RL, Faessen GH, Braat DD, Fauser BC \& Giudice LC Serum and follicular fluid levels of insulin-like growth factor I (IGF-I), IGF-II, and IGF-binding protein-1 and -3 during the normal menstrual cycle. Journal of Clinical Endocrinology and Metabolism 199681 1224-1231.

44 Ovesen P, Vahl N, Fisker S, Veldhuis JD, Christiansen JS \& Jorgensen JO. Increased pulsatile, but not basal, growth hormone secretion rates and plasma insulin-like growth factor I levels during the periovulatory interval in normal women. Journal of Clinical Endocrinology and Metabolism 199883 1662-1667.

45 Cardim HJ, Lopes CM, Giannella-Neto D, da Fonseca AM \& Pinotti JA. The insulin-like growth factor-I system and hormone replacement therapy. Fertility and Sterility 200175 282-287.

46 Raudaskoski T, Knip M \& Laatikainen T. Plasma insulin-like growth factor-I and its binding proteins- 1 and -3 during continuous non oral and oral combined hormone replacement therapy. Menopause $19985217-222$.
47 Kam GY, Leung KC, Baxter RC \& Ho KK. Estrogens exert routeand dose-dependent effects on insulin-like growth factor(IGF)binding protein-3 and acid-labile subunit of the IGF ternary complex. Journal of Clinical Endocrinology and Metabolism 2000 85 1918-1922.

48 Dall'Aglio E, Valenti G, Hoffman AR, Zuccarelli A, Passeri M \& Ceda GP. Lack of effect of transdermal estrogen on the growth hormone-insulin-like growth factor axis. Hormone and Metabolic Research 199426 211-212.

49 Gentili A, Mulligan T, Godschalk M, Clore J, Patrie J, Iranmanesh A \& Veldhuis JD. Unequal impact of short-term testosterone repletion on the somatotropic axis of young and older men. Journal of Clinical Endocrinology and Metabolism 200287 825-834.

50 Fryburg DA, Weltman A, Jahn LA, Weltman JY, Samojlik E, Hintz RL \& Veldhuis JD. Short-term modulation of the androgen milieu alters pulsatile, but not exercise- or growth hormone (GH)-releasing hormone-stimulated GH secretion in healthy men: impact of gonadal steroid and GH secretory changes on metabolic outcomes. Journal of Clinical Endocrinology and Metabolism 199782 3710-3719.

51 Azziz R, Deal CL, Potter HD, Gargosky SE \& Rosenfeld RG. Regulation of extragonadal insulin-like growth factor-binding protein-3 by testosterone in oophorectomized women. Journal of Clinical Endocrinology and Metabolism 199479 1747-1751.

52 Molnar P \& Murphy LJ. Effects of oestrogen on rat uterine expression of insulin-like growth factor-binding proteins. Journal of Molecular Endocrinology 199413 59-67.

53 Adesanya OO, Zhou J \& Bondy CA. Cellular localization and sex steroid regulation of insulin-like growth factor binding protein messenger ribonucleic acids in the primate myometrium. Journal of Clinical Endocrinology and Metabolism 199681 2495-2501.

54 Clapper JA, Snyder JL, Roberts AJ, Hamernik DL \& Moss GE. Estradiol increases relative amounts of insulin-like growth factor binding protein (IGFBP)-3 in serum and expression of IGFBP-2 in anterior pituitaries of ewes. Biology of Reproduction $1998 \mathbf{5 9}$ $124-130$.

55 Heald AH, Cruickshank JK, Riste LK, Cade JE, Anderson S, Greenhalgh A, Sampayo J, Taylor W, Fraser W, White A \& Gibson JM. Close relation of fasting insulin-like growth factor binding protein-1 (IGFBP-1) with glucose tolerance and cardiovascular risk in two populations. Diabetologia 200144 333-339.

56 Miyakoshi N, Richman C, Qin X, Baylink DJ \& Mohan S. Effects of recombinant insulin-like growth factor-binding protein-4 on bone formation parameters in mice. Endocrinology $1999 \mathbf{1 4 0}$ 5719-5728.

57 Rees C, Clemmons DR, Horvitz GD, Clarke JB \& Busby WH. A protease-resistant form of insulin-like growth factor (IGF) binding protein 4 inhibits IGF-I actions. Endocrinology $1998 \quad 139$ $4182-4188$.

Received 21 September 2004

Accepted 27 December 2004 